\title{
Pubertal timing and body mass index gain from birth to maturity in relation with femoral neck BMD and distal tibia microstructure in healthy female subjects
}

\author{
T. Chevalley $\cdot$ J. P. Bonjour $\cdot$ S. Ferrari $\cdot$ R. Rizzoli
}

Received: 4 October 2010 / Accepted: 17 December 2010/Published online: 26 February 2011

(C) The Author(s) 2011. This article is published with open access at Springerlink.com

\begin{abstract}
Summary Childhood body mass index (BMI) gain is linked to hip fracture risk in elderly. In healthy girls, menarcheal age is inversely related to BMI gain during childhood and to femoral neck areal bone mass density (aBMD) and distal tibia structural components at maturity. This study underscores the importance of pubertal timing in age-related fragility fracture risk.

Introduction Recent data point to a relationship between BMI change during childhood and hip fracture risk in later life. We hypothesized that BMI development is linked to variation in pubertal timing as assessed by menarcheal age (MENA) which in turn, is related to peak bone mass (PBM) and hip fracture risk in elderly.

Methods We studied in a 124 healthy female cohort the relationship between MENA and BMI from birth to maturity, and DXA-measured femoral neck (FN) aBMD at 20.4 year. At this age, we also measured bone strength related microstructure components of distal tibia by HR-pQCT.

Results At $20.4 \pm 0.6$ year, FN aBMD $\left(\mathrm{mg} / \mathrm{cm}^{2}\right)$, cortical thickness $(\mu \mathrm{m})$, and trabecular density $\left(\mathrm{mg} \mathrm{HA} / \mathrm{cm}^{3}\right)$ of distal tibia were inversely related to MENA $(P=0.023$, 0.015 , and 0.041 , respectively) and positively to BMI changes from 1.0 to 12.4 years $(P=0.031,0.089,0.016$, respectively). Significant inverse $(P<0.022$ to $<0.001)$ correlations $(R=-0.21$ to -0.42$)$ were found between MENA and BMI from 7.9 to 20.4 years, but neither at birth nor at 1.0 year. Linear regression indicated that
\end{abstract}

T. Chevalley $(\varangle) \cdot J$. P. Bonjour $\cdot$ S. Ferrari $\cdot$ R. Rizzoli Division of Bone Diseases, Department of Rehabilitation and Geriatrics, Geneva University Hospitals and Faculty of Medicine,

Rue Micheli-du-Crest 24,

CH-1211, Geneva 14, Switzerland

e-mail: Thierry.Chevalley@hcuge.ch
MENA Z-score was inversely related to BMI changes not only from 1.0 to 12.4 years $(R=-0.35, P=0.001)$, but also from 1.0 to 8.9 years, $(R=-0.24, P=0.017)$, i.e., before pubertal maturation.

Conclusion BMI gain during childhood is associated with pubertal timing, which in turn, is correlated with several bone traits measured at PBM including FN aBMD, cortical thickness, and volumetric trabecular density of distal tibia. These data complement the reported relationship between childhood BMI gain and hip fracture risk in later life.

Keywords BMI development - Distal tibia microstructure . Femoral neck BMD $\cdot$ Menarcheal age $\cdot$ Peak bone mass

\section{Introduction}

In healthy human subjects, bone mineral mass follows a trajectory from birth on to attain a maximal value, the socalled peak bone mass (PBM), by the end of the second or the beginning of the third decade, according to both gender and skeletal sites examined [1].

Later menarcheal age was shown to be a risk factor for reduced bone mineral mass in postmenopausal women [2-7] and increased prevalence of fragility fractures at several sites of the skeleton [8-11].

The negative influence of later menarcheal age on bone mineral mass observed in postmenopausal women is already expressed long before menopause as it was observed in middle-age premenopausal women with mean age 45 years, and in healthy young adult females in their very early twenties [12]. Furthermore, this influence of pubertal timing on peak bone mass was found to be predetermined before the onset of pubertal maturation in a prospective follow-up study from age 8 to 20 years [13]. 
This suggested that both pubertal timing and bone traits may be under the influence of common genetic factors [14].

The risk of hip fracture is dependent upon the amount of areal bone mineral density (aBMD) or bone mineral content (BMC) as assessed by osteodensitometry at the level of proximal femur, particularly in the femoral neck (FN). Longitudinal studies of women ranging from 20 to 94 years with follow-up periods from 16 to 22 years showed that the average annual rate of bone loss was relatively constant and tracked well within individuals $[15,16]$. Furthermore, a high correlation was recorded between the baseline aBMD values and those obtained after $16(R=0.83)$ [15] and $22(R=0.80)$ years of follow-up [16]. This tracking pattern of aBMD is thus maintained over six decades of adult life. Such a notion has two important implications. First, the prediction of hip fracture risk based on one single measurement of FN aBMD remains reliable in the long term $[15,16]$. Second, within the wide range of $\mathrm{FN}$ aBMD values little variation occurs during adult life in individual Z-scores or percentiles. Hence, it can be inferred that bone mass acquired by the end of the growth period appears to be more important than bone loss occurring during adult life [17].

This tracking pattern of FN aBMD was also reported in healthy females, from prepuberty to peak bone mass attainment [18-20]. In fact, since PBM is under strong genetic influence [21-23], it can be expected that bone mineral density and size are found to significantly track during growth in healthy populations throughout the world $[18,20,24-26]$.

Growth in infancy was reported to be associated with BMC in later life [27]. The risk of hip fracture in elderly was shown to be related to early variation in height and weight growth $[28,29]$. Very recently, in a study of 6,370 women born in Finland, reduction in body mass index (BMI) gain between 1 and 12 years of age was associated with an increase risk of hip fracture in later life [30]. Two potential explanations for this link between reduction in Zscore for BMI and later fracture risk are discussed by the authors: first, a difference in pubertal timing; second, a slowing of growth in response to adverse environmental influences [30]. The authors concluded that thinness in childhood is a risk factor for hip fracture in later life, by a direct effect of low fat mass on bone mineralization or represents the influence of altered timing of pubertal maturation. In this study, the timing of puberty as precisely assessed by prospectively recording menarcheal age, was not determined [30], making uncertain whether this important determinant of FN PBM and subsequent premenopausal FN aBMD [12] could be implicated in this association.

In the present report, we tested the hypothesis that variation in body growth during infancy and childhood are related to pubertal timing which, in turn is a determinant of
FN peak bone mass. Data are presented on the relationship between menarcheal age and body weight $(\mathrm{BW})$, height $(\mathrm{H})$ and BMI from birth to 20 years, and in FN aBMD prospectively measured from prepuberty to maturity in a cohort of healthy females. In addition to FN PBM measurements, we also analyzed whether the impact of BMI as linked to pubertal timing was detectable on bone strength related microstructure, as assessed by high resolution peripheral computerized tomography (HR-pQCT) at the level of distal tibia.

\section{Subjects and methods}

\section{Participants}

We studied 124 healthy women with mean $( \pm \mathrm{SD})$ age of $20.4 \pm 0.6$ year. They belong to a cohort followed during 12 years and previously examined at mean age $7.9 \pm 0.5,8.9 \pm$ $0.5,10.0 \pm 0.5$ [31], $12.4 \pm 0.5$ [32], and $16.4 \pm 0.5$ year [33]. During 1 year, between mean age of 7.9 and 8.9 years, half the cohort received a supplementation of calcium in a randomized, double-blind, placebo-controlled design, as previously reported [31]. Exclusion criteria at baseline were: ratio of weight/height $<3$ rd or $>97$ th percentile, physical signs of puberty, chronic disease, malabsorption, bone disease, and regular use of medication as previously described [31].

The ethics committees of the Department of Pediatrics and the Department of Rehabilitation and Geriatrics of the University Hospitals of Geneva approved the protocol while informed consent was obtained from both parents and children [31]. All subjects were recruited within the Geneva area.

\section{Clinical assessment}

Body weight, standing height, and BMI $\left(\mathrm{kg} / \mathrm{m}^{2}\right)$ were retrospectively obtained at birth $(n=115)$ and 1 year of age $(n=96)$ through questionnaires sent to the parents and the pediatricians. These anthropometric variables were then prospectively measured at each visit from 7.9 years of age on. At mean age $( \pm \mathrm{SD}) 7.9 \pm 0.5$ and $8.9 \pm 0.5$ year, pubertal stage was assessed by direct clinical examination made by a pediatrician-endocrinologist. At mean age of 10.0, 12.4, and 16.4 years pubertal maturation was assessed by a selfassessment questionnaire with drawings and written description of Tanner's breast and pubic hair. At mean age 7.9 and 8.9 years, all girls were classified Tanner's stage P1 while at mean age of 10.0 years, $38 \%$ of them had reached Tanner's stage P2. Menarcheal age (MENA) was then assessed prospectively by direct interview at the second, third, fourth, and fifth visits, i.e., at the mean age of 8.9, $10.0,12.4$, and 16.4 years. MENA was within physiological 
range in all girls according to reference values established in the general population living in the same area [33]. Moreover, there was no case of pathological delayed or precocious puberty. The use of contraceptive pill for more than 3 months was recorded as well as smoking expressed in yearly pack units.

\section{Calcium intake}

At each visit from 7.9 years, spontaneous, i.e., baseline calcium intake, as essentially assessed from dairy sources, was estimated by a frequency questionnaire [34].

Measurement of bone variables

Areal bone mineral density $\left(\mathrm{mg} / \mathrm{cm}^{2}\right)$ was measured by dual-energy X-ray absorptiometry (DXA) at the level of the femoral neck (FN) with a Hologic QDR-4500 instrument (Waltham, MA, USA), as previously reported [33]. The coefficient of variation of repeated aBMD measurements varied between $1.0 \%$ and $1.6 \%$ [33].Volumetric bone density and microstructure were determined at the distal tibia by HR-pQCT on an XtremeCT instrument (Scanco medical $A^{\circledR}{ }^{\circledR}$, Basserdorf, Switzerland), as previously described [35]. At the distal tibia, 110 parallel CT slices with a nominal resolution (voxel size) of $82 \mu \mathrm{m}$ were obtained, thus delivering a three-dimensional representation of approximately $9 \mathrm{~mm}$ in the axial direction. An anteroposterior scout view was used to define the measurement region. Briefly, a reference line was manually placed at the endplate of the tibia and the first $\mathrm{CT}$ slice was $22.5 \mathrm{~mm}$ distal to the reference line. The following variables were measured: total (Dtot), cortical (Dcort), and trabecular (Dtrab) volumetric bone density expressed as $\mathrm{mg}$ hydroxyapatite (HA) $/ \mathrm{cm}^{3}$; trabecular bone volume fraction (BV/TV, \%), trabecular number (Tb.N), thickness (Tb.Th, $\mu \mathrm{m})$ and spacing (Tb.Sp, $\mu \mathrm{m})$; mean cortical thickness (Ct. $\mathrm{Th}, \mu \mathrm{m})$ and cross-sectional area $\left(\mathrm{CSA}, \mathrm{mm}^{2}\right)$. The in vivo short-term reproducibility of HR-pQCT at the distal tibia assessed in 15 subjects with repositioning varied from $0.7 \%$ to $1.0 \%$ and from $3.0 \%$ to $4.9 \%$ for bone density and for trabecular architecture, respectively. These reproducibility ranges in our facility are similar to those recently published [36].

Expression of the results and statistical analysis

The various anthropometric and osteodensitometric variables are given as mean \pm SD. MENA and BMI as well as FN aBMD or distal tibia Ct.Th and Dtrab were expressed in Zscores computed from this healthy female cohort. The mean values of anthropometric variable gains were expressed either in absolute terms or as the difference of the relative
(Z-score) values at the different ages. A multivariate model adjusted for repeated measures using individual values of age and BMI Z-score at each visit was performed to demonstrate the overall significant association between BMI Z-score and MENA Z-score $(\beta=-0.256, P \leq 0.001$, $R^{2}=0.07$ ). Since an improvement in the coefficient of determination $\left(R^{2}\right)$ was observed when the model was repeated without taking into account values at birth and 1 year of age, we looked at which age the relationship between BMI Z-score and menarcheal age Z-score was most significant. Then, univariate analysis at different time points were performed between BMI Z-score and MENA Z-score and between delta BMI Z-score and MENA Zscore. The relationships between bone traits expressed in Zscores and MENA Z-score or delta BMI expressed in absolute terms were also examined by univariate regression analysis. The subjects were segregated according to the median of menarcheal age. Timing of menarche (MENA) under and above the median age of the first menstruation was defined as "EARLIER" and "LATER," respectively. The differences in anthropometric characteristics between EARLIER and LATER MENA were assessed by unpaired Student's $t$ test or by Wilcoxon signed rank test according to the variable distribution pattern. The significance level for two-sided $P$ values was 0.05 for all tests. The data were analyzed using STATA software, version 9.0 (StataCorp LP, College Station, TX, USA).

\section{Results}

The whole cohort anthropometric variables from birth on and the development of DXA-measured FN aBMD from prepuberty to early twenties are described in Table 1. All values are within the reference ranges of the corresponding population of healthy female subjects. Among the 124 young women, $64(51.6 \%)$ were current $(n=50)$ or previous smokers $(n=14)$. The use of contraceptive pill for more than 3 months concerned 24 (19.4\%) young women. There was no significant difference between girls with $(n=96)$ and without $(n=28)$ birth weight and infant weight in terms of BMI, femoral neck aBMD and distal tibia pQCT values at the mean age of 20.4 years. At birth and at 1.0 year of age, there was no relationship between future menarcheal age, taken as a precise assessment of pubertal timing, and BMI (Table 2). In contrast, highly significant inverse regression coefficients $(\beta)$ were recorded at the age of 7.9 and 8.9 years, i.e., when all girls were still prepubertal as indicated in the legend in Table 1. The inverse regression coefficient still became maximally negative at the age of 12.4 year $(\beta=-0.455, P<0.001)$. At this age, MENA explained $18 \%$ of the BMI variance $\left(R^{2}=0.18\right)$ (Table 2 ). Afterwards, the negative slope regression of BMI on 
Table 1 Anthropometric and femoral neck aBMD data from birth to 20.4 years in healthy girls

\begin{tabular}{lllll}
\hline Age (year/s) & $\begin{array}{l}\text { Weight } \\
\mathrm{kg}\end{array}$ & $\begin{array}{l}\text { Height } \\
\mathrm{cm}\end{array}$ & $\begin{array}{l}\mathrm{BMI} \\
\mathrm{kg} / \mathrm{cm}^{2}\end{array}$ & $\begin{array}{l}\mathrm{FN} \mathrm{aBMD} \\
\mathrm{mg} / \mathrm{cm}^{2}\end{array}$ \\
\hline $\begin{array}{l}\text { Birth } \\
n=115\end{array}$ & $3.2 \pm 0.4$ & $49.3 \pm 2.1$ & $13.0 \pm 1.2$ & $\mathrm{NA}$ \\
$\begin{array}{l}1 \\
n=96\end{array}$ & $9.2 \pm 0.9$ & $73.9 \pm 3.4$ & $16.9 \pm 1.4$ & $\mathrm{NA}$ \\
$\begin{array}{l}7.9 \pm 0.5 \\
n=124\end{array}$ & $26.5 \pm 4.1$ & $127.7 \pm 5.9$ & $16.2 \pm 1.8$ & $634 \pm 74$ \\
$\begin{array}{c}8.9 \pm 0.5 \\
n=123\end{array}$ & $29.8 \pm 4.9$ & $132.7 \pm 6.1$ & $16.9 \pm 2.1$ & $647 \pm 75$ \\
$\begin{array}{l}10.0 \pm 0.5 \\
n=114\end{array}$ & $33.2 \pm 5.7$ & $138.8 \pm 6.7$ & $17.1 \pm 2.1$ & $675 \pm 78$ \\
$\begin{array}{l}12.4 \pm 0.5 \\
n=106\end{array}$ & $44.5 \pm 8.1$ & $153.8 \pm 7.9$ & $18.7 \pm 2.5$ & $751 \pm 103$ \\
$\begin{array}{c}16.4 \pm 0.5 \\
n=113\end{array}$ & $56.8 \pm 7.9$ & $164.0 \pm 6.2$ & $21.1 \pm 2.7$ & $867 \pm 111$ \\
$\begin{array}{c}20.4 \pm 0.6 \\
n=124\end{array}$ & $60.0 \pm 9.2$ & $165.0 \pm 6.0$ & $22.1 \pm 3.4$ & $858 \pm 108$ \\
\hline
\end{tabular}

All values are mean \pm SD. The percent of girls having experienced their first menstruations was: $0,1.8$, and $25.5 \%$ at the age of $8.9,10.0$, and 12.4 years, respectively. All participants were menstruating at the visit when their mean age was 16.4. \pm 0.5 year

$B M I$ body mass index, $F N$ Femoral neck, $a B M D$ areal bone mineral density, $N A$ not available

MENA was less steep, but still remained statistically significant at the beginning of the third decade (Table 2).

Regression coefficients were also calculated between MENA and BMI gains (Table 2). No relationship was found with BMI increment from birth to 1.0 year of age. In contrast, the regression coefficient of BMI gain on MENA was inversely related from 1.0 to 8.9 years, and 10.0 and 12.4 years. At this age, the negative slope of BMI gain on MENA was the steepest (Table 2). The regression coefficient was no longer significantly less than zero at 16.4 and 20.4 years of age. Adjustment by smoking and contraceptive pill use did not modify the statistical significance of the regressions calculated between BMI Z-score or gain in BMI $\mathrm{Z}$-score at 16.4 and 20 years of age and menarcheal age Zscore (Table 2).

As shown in Fig. 1a, b and c, the slopes of the linear regressions between $\mathrm{FN}$ aBMD, Ct.Th, and BV/TV of distal tibia, measured at 20.4 years, and MENA are negative. It ensues that the relationships between these three bone variables and BMI gains from 1 to 12.4 years are positively related (Fig. 1d, e, and f).

The relation between pubertal timing and both anthropometric and bone variables was further analyzed by segregating the cohort by the median (12.9 years) of MENA. At birth and 1 year of age, no difference in BW, $\mathrm{H}$, and thereby in BMI was detected between girls who will experience pubertal timing below (EARLIER) and above
Table 2 Regressions between Z-scores of body mass index (BMI) and menarcheal age (A) and between delta Z-scores of BMI and menarcheal age (B)

\begin{tabular}{|c|c|c|c|c|c|c|}
\hline & \multirow[t]{2}{*}{$N$} & \multirow[t]{2}{*}{$\beta$} & \multirow[t]{2}{*}{$P$} & \multicolumn{2}{|c|}{$95 \% \mathrm{CI}$ for } & \multirow[t]{2}{*}{$R^{2}$} \\
\hline & & & & Lower & Upper & \\
\hline \multicolumn{7}{|l|}{ A) } \\
\hline \multicolumn{7}{|c|}{ Age (year/s) } \\
\hline Birth & 115 & -0.070 & 0.468 & -0.259 & 0.120 & 0.01 \\
\hline 1 & 96 & -0.026 & 0.804 & -0.237 & 0.184 & 0.01 \\
\hline 7.9 & 124 & -0.336 & 0.000 & -0.505 & -0.167 & 0.11 \\
\hline 8.9 & 123 & -0.337 & 0.000 & -0.506 & -0.169 & 0.11 \\
\hline 10.0 & 114 & -0.341 & 0.000 & -0.515 & -0.166 & 0.12 \\
\hline 12.4 & 105 & -0.455 & 0.000 & -0.644 & -0.265 & 0.18 \\
\hline 16.4 & 113 & -0.327 & $\begin{array}{c}0.001 \\
(0.001)^{\mathrm{a}}\end{array}$ & -0.510 & -0.137 & 0.10 \\
\hline 20.4 & 124 & -0.208 & $\begin{array}{c}0.020 \\
(0.018)^{\mathrm{a}}\end{array}$ & -0.383 & -0.033 & 0.04 \\
\hline \multicolumn{7}{|l|}{ B) } \\
\hline \multicolumn{7}{|c|}{ Delta age (years) } \\
\hline Birth to 1 & 96 & -0.048 & 0.734 & -0.328 & 0.232 & 0.01 \\
\hline 1 to 7.9 & 96 & -0.245 & 0.058 & -0.499 & 0.009 & 0.04 \\
\hline 1 to 8.9 & 96 & -0.260 & 0.050 & -0.519 & 0.000 & 0.04 \\
\hline 1 to 10.0 & 92 & -0.356 & 0.010 & -0.624 & -0.088 & 0.07 \\
\hline 1 to 12.4 & 88 & -0.417 & 0.006 & -0.710 & -0.123 & 0.08 \\
\hline 1 to 16.4 & 92 & -0.199 & $\begin{array}{c}0.268 \\
(0.089)^{\mathrm{a}}\end{array}$ & -0.553 & 0.156 & 0.01 \\
\hline 1 to 20.4 & 96 & -0.167 & $\begin{array}{c}0.243 \\
(0.076)^{\mathrm{a}}\end{array}$ & -0.448 & 0.115 & 0.02 \\
\hline
\end{tabular}

CI confidence interval

${ }^{\mathrm{a}}$ After adjustment for smoking and contraceptive pill use

(LATER) the median of MENA (Table 3). From 7.9 to 12.4 years, BW, $\mathrm{H}$, and BMI rose significantly, more in EARLIER than LATER MENA subgroup. The differences in these anthropometric variables culminated at 12.4 years of age. They remained statistically significant at 16.4 years for both BW and BMI, but not for $\mathrm{H}$. At 20.4 years, there was still a trend for greater BW and BMI in the EARLIER than in the LATER subgroup (Table 3). From 7.9 to 20.4 years, FN aBMD was constantly greater in the EARLIER than LATER subgroup. The difference was the greatest $(+14.1 \%)$ at 12.4 years, then declined but remained statistically significant at 20.4 years $(+4.8 \%)$.

The differences in BW, $\mathrm{H}$, and BMI gains from birth to 1 year and from 1.0 to 7.9 years up to 20.4 years between the EARLIER and LATER subgroups are presented in Table 4. These differences corroborate the absolute values indicating that the pubertal timing influence is expressed on the gains from 1.0 to 7.4 years on, but not from birth to 1.0 year (Table 4 ).

Figure 2 illustrates the gains in BMI as expressed in Zscore from 1.0 to 7.9 years on, in EARLIER as compared to LATER subgroup. Under the histogram, the distribution of 
a $\quad y=-0.2035 x-0.0002, R=-0.20, P=0.023$
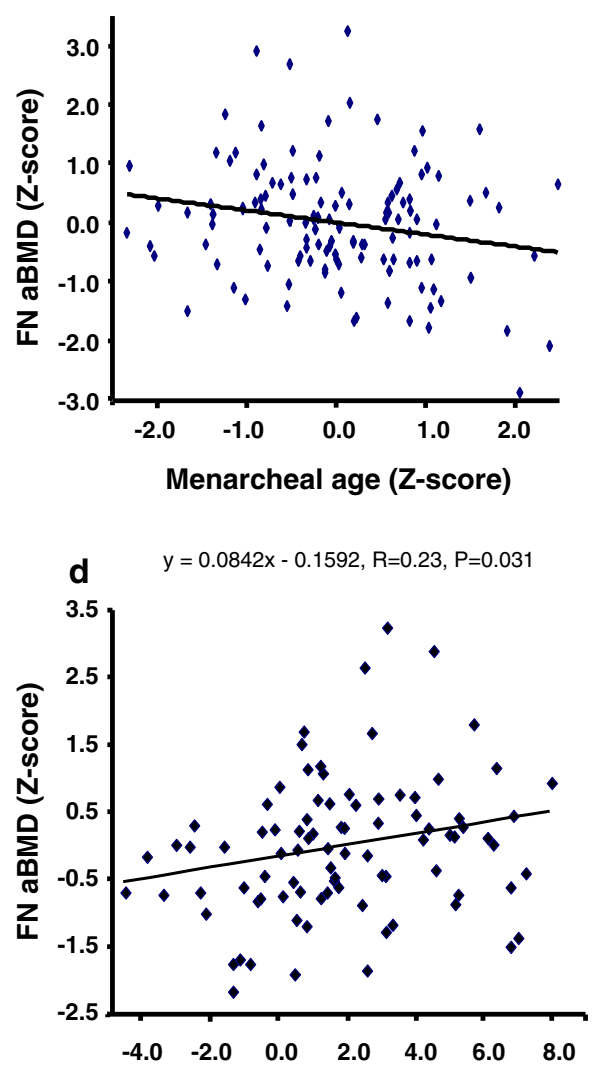

$\Delta \mathrm{BMI}$ from 1.0 to $12.4 \mathrm{yr}\left(\mathrm{kg} / \mathrm{m}^{2}\right)$ b
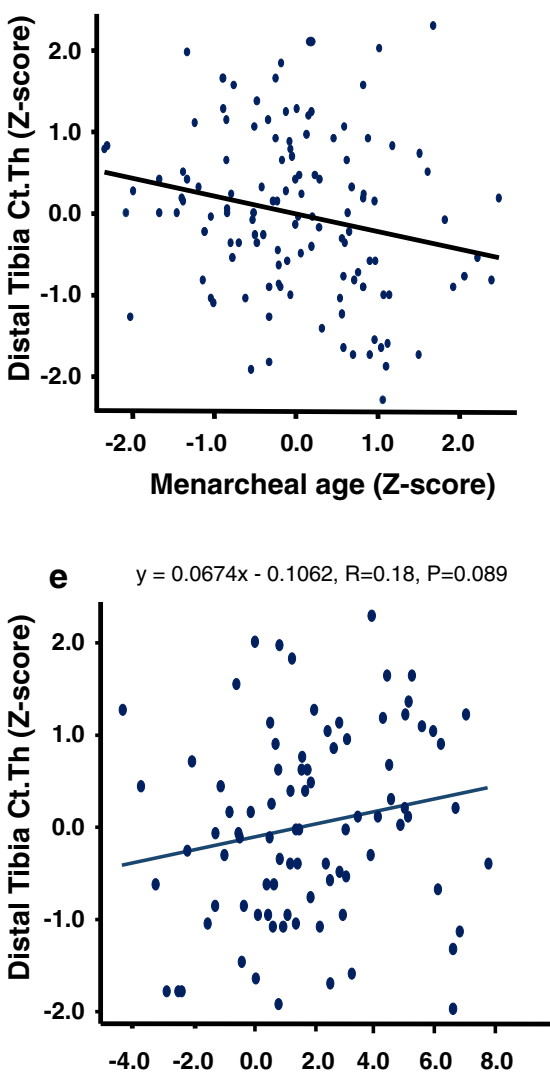

$\Delta$ BMI from 1.0 to $12.4 \mathrm{yr}\left(\mathrm{kg} / \mathrm{m}^{2}\right)$
C $\quad y=-0.1857 x-0.0105, R=-0.18, P=0.041$
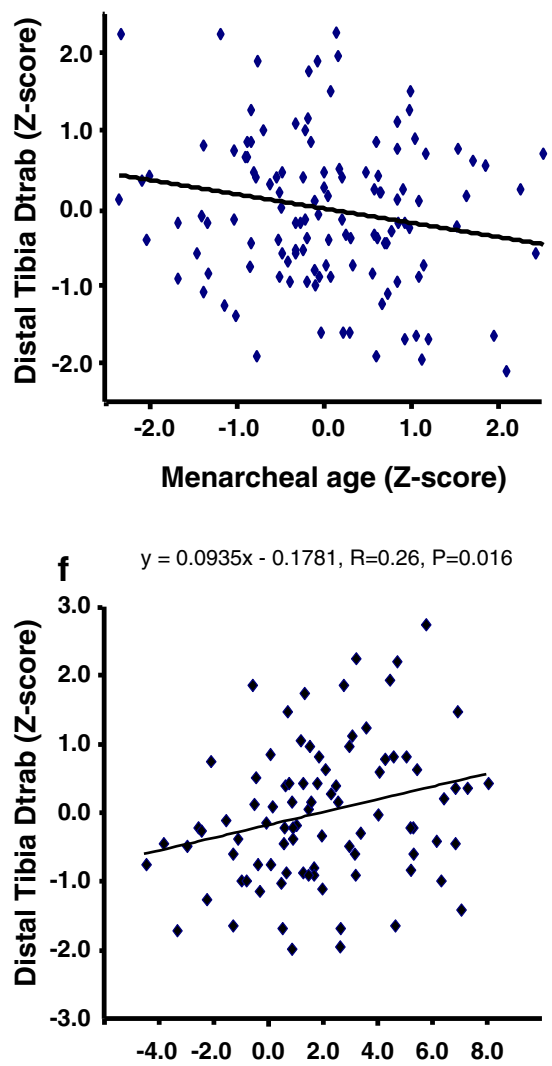

$\Delta \mathrm{BMI}$ from 1.0 to $12.4 \mathrm{yr}\left(\mathrm{kg} / \mathrm{m}^{2}\right)$
Fig. 1 Femoral neck aBMD, cortical thickness, and trabecular bone density of distal tibia measured at peak bone mass: relation with menarcheal age and change in BMI during childhood. The six linear regressions were calculated with the data prospectively recorded in 124 healthy girls. The regression equations are indicated above each

the pubertal stages from P1 to P5 documents the difference in the age-related progression of sexual maturation between the two MENA subgroups.

\section{Discussion}

The recently published report from Javaid et al. [30] showed that change in BMI during childhood, from 1 to 12 years, was inversely associated with hip fracture risk in later life. As potential explanations, the authors suggested either a direct effect of low fat mass on bone mineralization or altered timing of pubertal maturation [30]. Our study carried out in a cohort of healthy females whose BMI remained within the normal range complements this report by demonstrating that femoral neck aBMD measured by the end of skeletal development is also linked to gain in BMI during a very similar time interval, precisely from 1 to 12.4 years. Furthermore, our study documents that BMI gain during this time frame is inversely correlated with plot, with the corresponding correlation coefficient and the statistical $P$ values. The slopes of the three bone variables $(Y)$ are negatively and positively related to menarcheal age (upper plots: $\mathbf{a}, \mathbf{b}, \mathbf{c}$ ) and change in BMI from 1.0 to 12.4 years (lower plots: $\mathbf{d}, \mathbf{e}, \mathbf{f}$ ), respectively. See text for further details

pubertal timing as prospectively assessed by recording the age of menarche. We previously reported that in healthy adult females, a relatively later menarcheal age by 1.9 year is associated with a deficit in FN aBMD by nearly $0.4 \mathrm{~T}$ score [12]. Taking into account that FN aBMD tracks from early to late adulthood [15, 16], our observation should pertain to the risk of hip fracture in relation with childhood growth [30]. In the study by Javaid et al., BW and BMI measured at birth and 1 year of age were not related to hip fracture [30]. In the same way, our analysis did not reveal any relationship between these two anthropometric variables when measured either at birth or at $1 \mathrm{yr}$ of age and the pubertal timing recorded several years later.

The inverse association between gain in BW or BMI during childhood and menarcheal age may be interpreted as a direct effect of fat mass on the neuroendocrine system that triggers the timing of pubertal maturation [37]. Forty years ago, Frisch and Revelle [38] put forward the "critical weight" hypothesis suggesting that a minimum weight $(48 \mathrm{~kg})$ or body fat $(22 \%)$ should be attained to trigger the 
Table 3 Anthropometric and femoral neck aBMD data from birth to 20.4 years in healthy girls segregated by the median of menarcheal age

\begin{tabular}{|c|c|c|c|c|c|c|c|c|c|c|c|c|}
\hline \multirow[b]{2}{*}{$\begin{array}{l}\text { Age } \\
\text { (year/s) }\end{array}$} & \multicolumn{2}{|c|}{ Weight $(\mathrm{kg})$} & \multirow[t]{2}{*}{$P$} & \multicolumn{2}{|c|}{ Standing height $(\mathrm{cm})$} & \multirow[t]{2}{*}{$P$} & \multicolumn{2}{|c|}{$\begin{array}{l}\text { Body mass index } \\
(\mathrm{kg} / \mathrm{cm} 2)\end{array}$} & \multirow[t]{2}{*}{$P$} & \multicolumn{2}{|c|}{$\mathrm{FN}$ aBMD $\left(\mathrm{mg} / \mathrm{cm}^{2}\right)$} & \multirow[t]{2}{*}{$P$} \\
\hline & Earlier & Later & & Earlier & Later & & Earlier & Later & & Earlier & Later & \\
\hline Birth & $\begin{array}{c}3.2 \pm \\
0.4 \\
n=47\end{array}$ & $\begin{array}{c}3.2 \pm \\
0.4 \\
n=49\end{array}$ & 0.995 & $\begin{array}{c}49.4 \pm \\
2.2 \\
n=47\end{array}$ & $\begin{array}{c}49.2 \pm \\
1.9 \\
n=49\end{array}$ & 0.680 & $\begin{array}{c}13.0 \pm \\
1.2 \\
n=57\end{array}$ & $\begin{array}{c}13.1 \pm \\
1.3 \\
n=58\end{array}$ & 0.706 & NA & NA & \\
\hline 1 & $\begin{array}{c}9.1 \pm \\
0.9 \\
n=48\end{array}$ & $\begin{array}{c}9.3 \pm \\
1.0 \\
n=49\end{array}$ & 0.408 & $\begin{array}{c}73.9 \pm \\
3.2 \\
n=47\end{array}$ & $\begin{array}{c}74.0 \pm \\
3.6 \\
n=49\end{array}$ & 0.819 & $\begin{array}{c}16.7 \pm \\
1.1 \\
n=47\end{array}$ & $\begin{array}{c}17.0 \pm \\
1.6 \\
n=49\end{array}$ & 0.317 & NA & NA & \\
\hline $7.9 \pm 0.5$ & $\begin{array}{c}27.8 \pm \\
4.2 \\
n=62\end{array}$ & $\begin{array}{c}25.1 \pm \\
3.5 \\
n=62\end{array}$ & 0.0002 & $\begin{array}{c}129.1 \pm \\
5.7 \\
n=62\end{array}$ & $\begin{array}{c}126.3 \pm \\
5.7 \\
n=62\end{array}$ & 0.006 & $\begin{array}{c}16.6 \pm \\
1.9 \\
n=62\end{array}$ & $\begin{array}{c}15.7 \pm \\
1.6 \\
n=62\end{array}$ & 0.003 & $\begin{array}{l}640 \pm 71 \\
n=62\end{array}$ & $\begin{array}{l}628 \pm 77 \\
n=62\end{array}$ & 0.364 \\
\hline $8.9 \pm 0.5$ & $\begin{array}{c}31.6 \pm \\
5.0 \\
n=61\end{array}$ & $\begin{array}{c}28.1 \pm \\
4.0 \\
n=62\end{array}$ & 0.0001 & $\begin{array}{c}134.5 \pm \\
5.8 \\
n=61\end{array}$ & $\begin{array}{c}130.9 \pm \\
5.9 \\
n=62\end{array}$ & 0.0001 & $\begin{array}{c}17.4 \pm \\
2.2 \\
n=61\end{array}$ & $\begin{array}{c}16.4 \pm \\
1.8 \\
n=62\end{array}$ & 0.005 & $\begin{array}{l}658 \pm 72 \\
n=61\end{array}$ & $\begin{array}{l}636 \pm 77 \\
n=62\end{array}$ & 0.104 \\
\hline $10.0 \pm 0.5$ & $\begin{array}{c}35.4 \pm \\
5.6 \\
n=58\end{array}$ & $\begin{array}{c}30.9 \pm \\
4.9 \\
n=56\end{array}$ & 0.0001 & $\begin{array}{c}141.5 \pm \\
6.3 \\
n=58\end{array}$ & $\begin{array}{c}136.1 \pm \\
5.9 \\
n=56\end{array}$ & 0.0001 & $\begin{array}{c}17.6 \pm \\
2.1 \\
n=58\end{array}$ & $\begin{array}{c}16.6 \pm \\
2.0 \\
n=56\end{array}$ & 0.009 & $\begin{array}{l}689 \pm 72 \\
n=58\end{array}$ & $\begin{array}{l}661 \pm 81 \\
n=56\end{array}$ & 0.061 \\
\hline $12.4 \pm 0.5$ & $\begin{array}{c}48.6 \pm \\
6.4 \\
n=54\end{array}$ & $\begin{array}{c}40.2 \pm \\
7.4 \\
n=52\end{array}$ & 0.0001 & $\begin{array}{c}157.8 \pm \\
6.0 \\
n=54\end{array}$ & $\begin{array}{c}149.7 \pm \\
7.7 \\
n=52\end{array}$ & 0.0001 & $\begin{array}{c}19.5 \pm \\
2.2 \\
n=54\end{array}$ & $\begin{array}{c}17.8 \pm \\
2.5 \\
n=52\end{array}$ & 0.0004 & $\begin{array}{l}799 \pm 84 \\
n=54\end{array}$ & $\begin{array}{l}700 \pm 97 \\
n=52\end{array}$ & 0.001 \\
\hline $16.4 \pm 0.5$ & $\begin{array}{c}58.8 \pm \\
7.4 \\
n=57\end{array}$ & $\begin{array}{c}54.8 \pm \\
8.0 \\
n=56\end{array}$ & 0.007 & $\begin{array}{c}164.2 \pm \\
6.1 \\
n=57\end{array}$ & $\begin{array}{c}163.8 \pm \\
6.3 \\
n=56\end{array}$ & 0.751 & $\begin{array}{c}21.8 \pm \\
2.6 \\
n=57\end{array}$ & $\begin{array}{c}20.4 \pm \\
2.8 \\
n=56\end{array}$ & 0.005 & $\begin{array}{l}893 \pm 94 \\
n=57\end{array}$ & $\begin{array}{l}841 \pm 122 \\
n=56\end{array}$ & 0.014 \\
\hline $20.4 \pm 0.6$ & $\begin{array}{c}61.4 \pm \\
8.7 \\
n=62\end{array}$ & $\begin{array}{c}58.5 \pm \\
9.6 \\
n=62\end{array}$ & 0.085 & $\begin{array}{c}164.7 \pm \\
6.1 \\
n=62\end{array}$ & $\begin{array}{c}165.1 \pm \\
6.3 \\
n=62\end{array}$ & 0.703 & $\begin{array}{c}22.7 \pm \\
3.3 \\
n=62\end{array}$ & $\begin{array}{c}21.5 \pm \\
3.4 \\
n=62\end{array}$ & 0.051 & $\begin{array}{l}878 \pm 97 \\
n=62\end{array}$ & $\begin{array}{l}838 \pm 116 \\
n=62\end{array}$ & 0.042 \\
\hline
\end{tabular}

All values are mean $\pm \mathrm{SD}$. The percent of girls having experienced their first menstruations was: $0,1.8$, and $25.5 \%$ at the age of $8.9,10.0$, and 12.4 years, respectively. All were menstruating at the visit when their mean age was $16.4 \pm 0.5$ year

$B M I$ body mass index, $F N$ Femoral neck, $a B M D$ areal bone mineral density $N A$ not available

Table 4 Gains in anthropometric variables from birth to 1 year and from 1 year of age in healthy girls segregated by menarcheal age

\begin{tabular}{|c|c|c|c|c|c|c|c|c|c|}
\hline \multirow[t]{2}{*}{ Age (year/s) } & \multicolumn{2}{|c|}{ Weight (kg) } & \multirow[t]{2}{*}{$P$} & \multicolumn{2}{|c|}{ Height (cm) } & \multirow[t]{2}{*}{$P$} & \multicolumn{2}{|c|}{ BMI $\left(\mathrm{kg} / \mathrm{cm}^{2}\right)$} & \multirow[t]{2}{*}{$P$} \\
\hline & Earlier & Later & & Earlier & Later & & Earlier & Later & \\
\hline From birth to 1 & $\begin{array}{l}6.0 \pm 0.8 \\
n=47\end{array}$ & $\begin{array}{l}6.1 \pm 1.0 \\
n=49\end{array}$ & 0.506 & $\begin{array}{l}24.7 \pm 2.6 \\
n=47\end{array}$ & $\begin{array}{l}24.9 \pm 3.9 \\
n=49\end{array}$ & 0.810 & $\begin{array}{l}3.8 \pm 1.6 \\
n=47\end{array}$ & $\begin{array}{l}3.9 \pm 1.9 \\
n=49\end{array}$ & 0.907 \\
\hline 1 to 7.9 & $\begin{array}{l}18.4 \pm 3.9 \\
n=48\end{array}$ & $\begin{array}{l}15.9 \pm 3.4 \\
n=49\end{array}$ & 0.001 & $\begin{array}{l}55.2 \pm 5.3 \\
n=47\end{array}$ & $\begin{array}{l}52.2 \pm 5.7 \\
n=49\end{array}$ & 0.009 & $\begin{array}{l}-0.2 \pm 2.0 \\
n=47\end{array}$ & $\begin{array}{l}1.2 \pm 1.9 \\
n=49\end{array}$ & 0.013 \\
\hline 1 to 8.9 & $\begin{array}{l}22.1 \pm 4.8 \\
n=47\end{array}$ & $\begin{array}{l}18.9 \pm 4.0 \\
n=49\end{array}$ & 0.001 & $\begin{array}{l}60.7 \pm 5.4 \\
n=47\end{array}$ & $\begin{array}{l}56.9 \pm 5.9 \\
n=49\end{array}$ & 0.001 & $\begin{array}{l}0.5 \pm 2.4 \\
n=47\end{array}$ & $\begin{array}{l}-0.6 \pm 2.2 \\
n=49\end{array}$ & 0.023 \\
\hline 1 to 10.0 & $\begin{array}{l}26.3 \pm 5.4 \\
n=47\end{array}$ & $\begin{array}{l}21.8 \pm 4.9 \\
n=46\end{array}$ & 0.001 & $\begin{array}{l}67.8 \pm 6.0 \\
n=46\end{array}$ & $\begin{array}{l}62.5 \pm 6.3 \\
n=46\end{array}$ & 0.001 & $\begin{array}{l}1.0 \pm 2.2 \\
n=46\end{array}$ & $\begin{array}{l}-0.4 \pm 2.4 \\
n=46\end{array}$ & 0.005 \\
\hline 1 to 12.4 & $\begin{array}{l}39.2 \pm 6.2 \\
n=45\end{array}$ & $\begin{array}{l}32.0 \pm 7.7 \\
n=45\end{array}$ & 0.001 & $\begin{array}{l}83.7 \pm 5.6 \\
n=44\end{array}$ & $\begin{array}{l}76.0 \pm 8.7 \\
n=45\end{array}$ & 0.001 & $\begin{array}{l}2.8 \pm 2.4 \\
n=44\end{array}$ & $\begin{array}{l}1.0 \pm 2.9 \\
n=45\end{array}$ & 0.002 \\
\hline 1 to 16.4 & $\begin{array}{l}50.2 \pm 7.7 \\
n=45\end{array}$ & $\begin{array}{l}45.4 \pm 7.4 \\
n=47\end{array}$ & 0.002 & $\begin{array}{l}91.0 \pm 4.9 \\
n=45\end{array}$ & $\begin{array}{l}89.6 \pm 6.6 \\
n=47\end{array}$ & 0.231 & $\begin{array}{l}5.1 \pm 2.8 \\
n=45\end{array}$ & $\begin{array}{l}3.5 \pm 3.1 \\
n=47\end{array}$ & 0.009 \\
\hline 1 to 20.4 & $\begin{array}{l}53.0 \pm 9.1 \\
n=47\end{array}$ & $\begin{array}{l}50.0 \pm 10.1 \\
n=49\end{array}$ & 0.136 & $\begin{array}{l}91.0 \pm 5.3 \\
n=47\end{array}$ & $\begin{array}{l}91.3 \pm 6.6 \\
n=49\end{array}$ & 0.842 & $\begin{array}{l}6.1 \pm 3.7 \\
n=47\end{array}$ & $\begin{array}{l}4.7 \pm 3.8 \\
n=49\end{array}$ & 0.067 \\
\hline
\end{tabular}

All values are mean $\pm \mathrm{SD}$

$B M I$ body mass index 


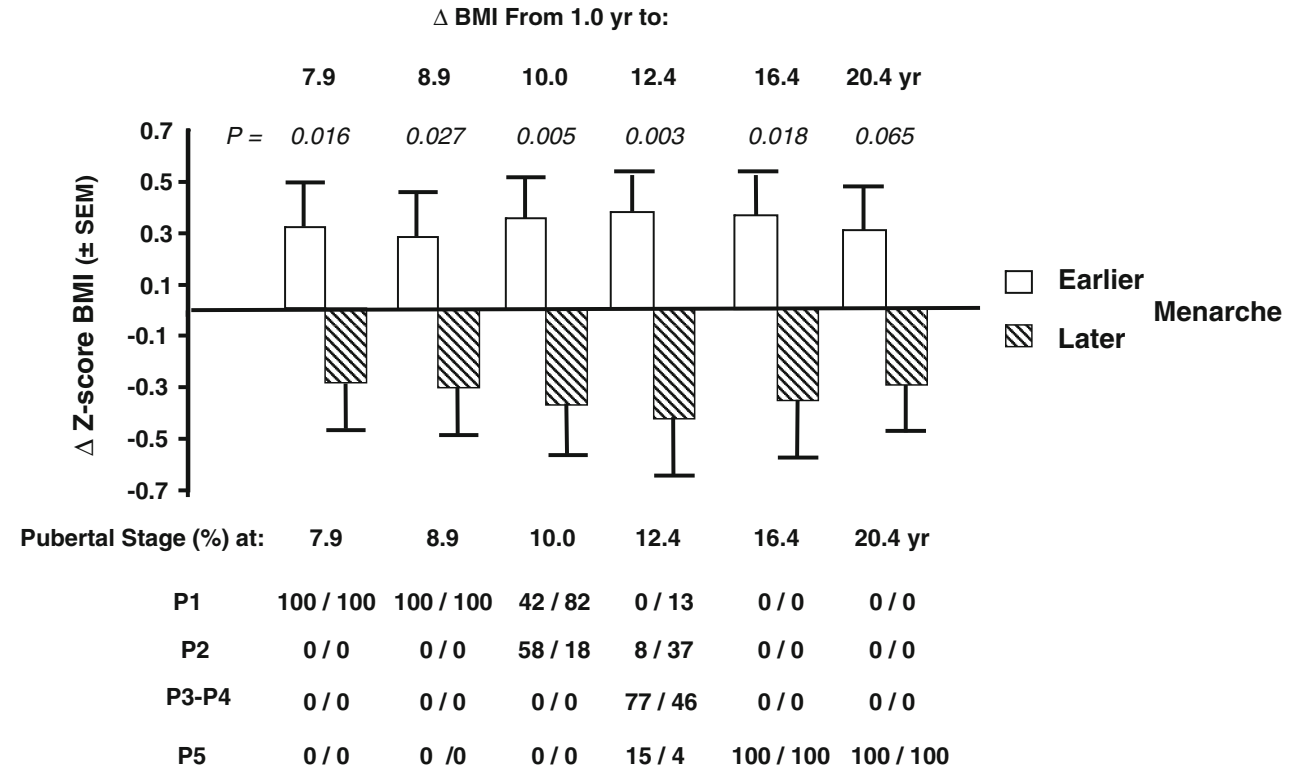

Fig. 2 Changes in BMI from 1.0 to 20.4 years in healthy subjects segregated by the median of menarcheal age. The diagram illustrates that the change in BMI Z-score from 1.0 year of age on between subjects with menarcheal age below (EARLIER) and above (LATER) the median is statistically significant at 7.9 and 8.9 years, an age at which all girls were still prepubertal (Tanner stage P1) as indicated below the diagram. The difference culminates at 12.4 years, and then

declines afterwards. Note that the progression of BMI from birth to 1.0 year of age was very similar in the EARLIER (from 13.0 to $16.7 \mathrm{~kg} / \mathrm{m}^{2}$ ) and LATER (from 13.1 to $17.0 \mathrm{~kg} / \mathrm{m}^{2}$ ) subgroups (see Table 3). The number of subjects for each age is presented in Table 3. See text for further details. $P$ values between EARLIER and LATER group at each age are indicated above the diagram

complex series of events leading to the development of secondary sexual features. More recently, some but not all epidemiologic studies from the United States of America [39] indicated that the secular trend of earlier puberty in girls would coincide with the progressing prevalence of overweight and obesity in children [40, 41]. Nevertheless, when this association was found, the question remained whether earlier pubertal timing was the result or cause of higher body fat [42]. Among putative nutrition or fat mass-related mediators, leptin was specially taken into account. From the analysis of experimental and clinical evidence, it emerges that leptin could not be considered as a critical factor [43] that would determine the wide interindividual variability in pubertal timing, as repeatedly observed in a large number of healthy adolescent populations [37, 44], as well as in our cohort with menarcheal age ranging from 10.2 to 16.0 years. Leptin should rather be considered as playing a permissive role in the triggering of the pubertal maturation process [43].

The secular trend in earlier puberty was also observed in a very large longitudinal multi-cohort study from Denmark with annual measurements of BW and $\mathrm{H}$ in 156,835 school children born from 1930 to 1969 [45, 46]. However, this trend was recorded irrespective of the BMI level as assessed at 7 years of age $[45,46]$. Thus, there is no evidence that fat mass would be an essential physiological factor causally implicated in the marked variability of pubertal maturation onset, as worldwide monitored in healthy children.

In our study, the difference in BMI gain between healthy, non-obese girls who will experience their first menses relatively earlier (12.1 years) and later (14.0 years), was already significant from 1.0 to 8.9 years of age. In absolute terms at 8.9 years of age, BW was $31.6 \pm 5.0$ and $28.1 \pm$ $4.0 \mathrm{~kg}$ in the earlier and later groups, respectively. The corresponding BMI values were $17.4 \pm 2.2$ and $16.4 \pm$ $1.8 \mathrm{~kg} / \mathrm{m}^{2}$ in the earlier and later subgroup, respectively. In a previous UK study in healthy girls of similar age (8.6 \pm 0.2 year), BW $(29.5 \pm 5.7 \mathrm{~kg})$, and $\mathrm{H}(1.31 \pm 0.05 \mathrm{~m})$, with BMI of $16.9 \mathrm{~kg} / \mathrm{m}^{2}$, fat mass was estimated from total body water measurement by deuterium dilution [47]. Using this validated method for measuring children body composition [48], fat mass amounted to $8.0 \pm 3.7 \mathrm{~kg}$ corresponding to $27 \%$ of BW [47]. In our study, the increased BW from 1.0 to 8.9 years of age was 22.1 and $18.9 \mathrm{~kg}$ in earlier and later maturers, respectively. Assuming the same adiposity percentage as that estimated by Wells and Cole [47], the corresponding difference in accumulated fat mass before the onset of pubertal maturation would be $0.864 \mathrm{~kg} \mathrm{(27 \%} \mathrm{of}$ $3.2 \mathrm{~kg}$ ). It is difficult to conceive that less than $1.0 \mathrm{~kg}$ of accumulated fat tissue from 1.0 to 8.9 years of age would so markedly delay the timing of puberty by nearly 2 years. For quantitative comparison, the secular trend of earlier pubertal timing in two nationally representative surveys of US girls studied 25 years apart, showed that menarcheal age declined from 12.75 to 12.54 years (12.80 to 12.60 years for white adolescents), corresponding to a 
decrease of two and a half months [49]. Between the two surveys, body weight measured in 10-year-old girls increased from 35.16 to $37.91 \mathrm{~kg}$ and BMI from 17.54 to $18.43 \mathrm{~kg} / \mathrm{m}^{2}$ [49]. Therefore, for differences in BW and BMI similar to those we recorded in our 8.9-year-old girls between earlier and later maturers, the secular trend for younger menarcheal age [49] was about ten times less than in our study, i.e., 2.5 vs. 22.8 months.

Based on accumulating contradictory evidence as reviewed by Wang [50], several previous reports [51-56] have questioned the "critical weight" hypothesis $[38,57]$ in the determination of menarche timing. Our study, as compared to the secular trend in earlier menarcheal age associated with increased prevalence of overweight and obesity [49] does not support the hypothesis causally linking fatness to pubertal timing. It appears more likely that the direction of causation is opposite, maturational timing affecting body composition [50].

Alike PBM, pubertal timing is under strong genetic influence, as documented by several twin and family studies [58-64]. Taking into account this strong influence of genetics on pubertal timing, the slight increase in BMI observed in non-obese healthy girls with relatively earlier menarcheal age could correspond to a secondary phenomenon and not to a causal determinant that would be mediated by some putative adipocyte-secreted factors responsible for activating the complex process of pubertal maturation. Therefore, there is no scientific argument to hamper considering pubertal timing as the independent variable that would predict $\mathrm{BW}$ and/or BMI, rather than the reverse.

The inverse relationship between the timing of puberty and bone mineral mass in adulthood has been often tentatively explained by a difference in estrogen exposure from prepuberty to PBM attainment. However in a recent analysis, we reported [13] that the difference in bone mineral mass between healthy girls experiencing relatively earlier (12.1 \pm 0.7 year) vs. later ( $14.0 \pm 0.7$ year) menarche was already present at 8.9 years of age, when all subjects were at Tanner stage P1, as assessed by direct examination by a pediatrician-endocrinologist. Moreover, from that prepubertal stage up to 20.4 years, aBMD gains at all skeletal sites examined were similar in earlier and later menarcheal age subgroups [13]. These results do not sustain the notion that difference in estrogen exposure from prepuberty to maturity would explain how pubertal timing could influence PBM and thereby subsequent risk of osteoporosis in later life.

Interestingly enough, the difference in PBM between African- and European-Americans [65] could not be attributed to faster gain in bone mineral mass during puberty [66]. This racial difference emerges by early childhood [67], although it is not observed in infants 1-18 months of age
[68]. The greater velocity of bone accrual in black than white Americans during childhood, but not during pubertal maturation, could well be related to racial difference in pubertal timing [66]. Such a relation would be compatible with the postulated concept linking pubertal timing and PBM acquisition by a common genetic programming [14].

In conclusion, in healthy girls, gain in BMI during childhood is associated with pubertal timing as prospectively assessed by recording menarcheal age. This reliable sexual maturation milestone is inversely correlated with several bone traits measured at peak bone mass, including femoral neck aBMD, cortical thickness, and volumetric trabecular density of distal tibia. These data are in accordance and complement further the reported relationship between childhood BMI gain and hip fracture risk in later life [30]. They strongly suggest that BMI gain in children with body weight within the normal range is influenced by pubertal timing as assessed by menarcheal age which in turn, has been shown in several postmenopausal women studies to be inversely related to aBMD or $\mathrm{BMC}$ and to increased risk of fragility fractures at several sites of the skeleton including at the hip level.

Acknowledgments We thank Giulio Conicella and the team of the Division of Nuclear Medicine for DXA and HR-pQCT measurements; Fanny Merminod, certified dietician, for the assessment of food intakes and her assistance in managing the study; Samuel Zamora, $\mathrm{MD}$, for his contribution to collect the anthropometric data; Pierre Casez, MD, for the elaboration of the database; François Herrmann, MD, MPH, for help with statistical analysis. We are indebted to Professor Dominique Belli, MD, chairman of the Department of Pediatrics at the Geneva University Hospitals, for his support in this research project. The Swiss National Science Foundation supported this study (Grant 3247BO-109799).

Conflicts of interest None.

Open Access This article is distributed under the terms of the Creative Commons Attribution Noncommercial License which permits any noncommercial use, distribution, and reproduction in any medium, provided the original author(s) and source are credited.

\section{References}

1. Bonjour JP, Theintz G, Law F, Slosman D, Rizzoli R (1994) Peak bone mass. Osteoporos Int 4(Suppl 1):7-13

2. Rosenthal DI, Mayo-Smith W, Hayes CW, Khurana JS, Biller BM, Neer RM, Klibanski A (1989) Age and bone mass in premenopausal women. J Bone Miner Res 4:533-538

3. Ribot C, Pouilles JM, Bonneu M, Tremollieres F (1992) Assessment of the risk of post-menopausal osteoporosis using clinical factors. Clin Endocrinol Oxf 36:225-228

4. Fox KM, Magaziner J, Sherwin R, Scott JC, Plato CC, Nevitt M, Cummings S (1993) Reproductive correlates of bone mass in elderly women. study of Osteoporotic Fractures Research Group. J Bone Miner Res 8:901-908 
5. Tuppurainen M, Kroger H, Saarikoski S, Honkanen R, Alhava E (1995) The effect of gynecological risk factors on lumbar and femoral bone mineral density in peri- and postmenopausal women. Maturitas 21:137-145

6. Ito M, Yamada M, Hayashi K, Ohki M, Uetani M, Nakamura T (1995) Relation of early menarche to high bone mineral density. Calcif Tissue Int 57:11-14

7. Varenna M, Binelli L, Zucchi F, Ghiringhelli D, Gallazzi M, Sinigaglia L (1999) Prevalence of osteoporosis by educational level in a cohort of postmenopausal women. Osteoporos Int 9:236-241

8. Johnell O, Gullberg B, Kanis JA, Allander E, Elffors L, Dequeker J, Dilsen G, Gennari C, Lopes Vaz A, Lyritis G et al (1995) Risk factors for hip fracture in European women: the MEDOS Study. Mediterranean Osteoporosis Study. J Bone Miner Res 10:1802-1815

9. Melton LJ 3rd (1997) Epidemiology of spinal osteoporosis. Spine 22:2S-11S

10. Silman AJ (2003) Risk factors for Colles' fracture in men and women: results from the European Prospective Osteoporosis Study. Osteoporos Int 14:213-218

11. Paganini-Hill A, Atchison KA, Gornbein JA, Nattiv A, Service SK, White SC (2005) Menstrual and reproductive factors and fracture risk: the Leisure World Cohort Study. J Womens Health (Larchmt) 14:808-819

12. Chevalley T, Bonjour JP, Ferrari S, Rizzoli R (2009) Deleterious effect of late menarche on distal tibia microstructure in healthy 20 year-old and premenopausal middle-aged women. J Bone Miner Res 24:144-152

13. Chevalley T, Bonjour JP, Ferrari S, Rizzoli R (2009) The influence of pubertal timing on bone mass acquisition: a predetermined trajectory detectable five years before menarche. J Clin Endocrinol Metab 94(9):3424

14. Bonjour JP, Chevalley T (2007) Pubertal timing, peak bone mass and fragility fracture risk. BoneKey-Osteovision 4:30-48, http:// www.bonekey-ibms.org/cgi/content/full/ibmske;34/32/30

15. Melton LJ 3rd, Atkinson EJ, O'Connor MK, O'Fallon WM, Riggs BL (2000) Determinants of bone loss from the femoral neck in women of different ages. J Bone Miner Res 15:24-31

16. Melton LJ 3rd, Atkinson EJ, Khosla S, Oberg AL, Riggs BL (2005) Evaluation of a prediction model for long-term fracture risk. J Bone Miner Res 20:551-556

17. Bonjour JP, Chevalley T, Rizzoli R, Ferrari S (2007) Geneenvironment interactions in the skeletal response to nutrition and exercise during growth. Med Sport Sci 51:64-80

18. Ferrari S, Rizzoli R, Slosman D, Bonjour JP (1998) Familial resemblance for bone mineral mass is expressed before puberty. $\mathrm{J}$ Clin Endocrinol Metab 83:358-361

19. Bonjour JP, Rizzoli R (2001) Bone acquisition in adolescence. In: Marcus R, Feldman D, Kelsey J (eds) Osteoporosis. Academic, San Diego, pp 621-638

20. Baxter-Jones AD, Mirwald RL, McKay HA, Bailey DA (2003) A longitudinal analysis of sex differences in bone mineral accrual in healthy 8-19-year-old boys and girls. Ann Hum Biol 30:160-175

21. Eisman JA (1999) Genetics of osteoporosis. Endocr Rev 20:788804

22. Ferrari S, Rizzoli R, Bonjour JP (1999) Genetic aspects of osteoporosis. Curr Opin Rheumatol 11:294-300

23. Peacock M, Turner CH, Econs MJ, Foroud T (2002) Genetics of osteoporosis. Endocr Rev 23:303-326

24. Foley S, Quinn S, Jones G (2009) Tracking of bone mass from childhood to adolescence and factors that predict deviation from tracking. Bone 44:752-757

25. Kalkwarf HJ, Gilsanz V, Lappe JM, Oberfield S, Shepherd JA, Hangartner TN, Huang X, Frederick MM, Winer KK, Zemel BS (2010) Tracking of bone mass and density during childhood and adolescence. J Clin Endocrinol Metab 95:1690-1698
26. Budek AZ, Mark T, Michaelsen KF, Molgaard C (2010) Tracking of size-adjusted bone mineral content and bone area in boys and girls from 10 to 17 years of age. Osteoporos Int 21:179-182

27. Cooper C, Fall C, Egger P, Hobbs R, Eastell R, Barker D (1997) Growth in infancy and bone mass in later life. Ann Rheum Dis $56: 17-21$

28. Cooper C, Eriksson JG, Forsen T, Osmond C, Tuomilehto J, Barker DJ (2001) Maternal height, childhood growth and risk of hip fracture in later life: a longitudinal study. Osteoporos Int 12:623-629

29. Cooper C, Westlake S, Harvey N, Javaid K, Dennison E, Hanson M (2006) Review: developmental origins of osteoporotic fracture. Osteoporos Int 17:337-347

30. Javaid K, Eriksoson J, Kajantie E, Forsen T, Osmond C, Barker D, Cooper C (2011) Growth in childhood predicts hip fracture risk in later life. Osteoporosis International 22(1):69-73

31. Bonjour JP, Carrie AL, Ferrari S, Clavien H, Slosman D, Theintz G, Rizzoli R (1997) Calcium-enriched foods and bone mass growth in prepubertal girls: a randomized, double-blind, placebocontrolled trial. J Clin Invest 99:1287-1294

32. Bonjour JP, Chevalley T, Ammann P, Slosman D, Rizzoli R (2001) Gain in bone mineral mass in prepubertal girls 3.5 years after discontinuation of calcium supplementation: a follow-up study. Lancet 358:1208-1212

33. Chevalley T, Rizzoli R, Hans D, Ferrari S, Bonjour JP (2005) Interaction between calcium intake and menarcheal age on bone mass gain: an eight-year follow-up study from prepuberty to postmenarche. J Clin Endocrinol Metab 90:44-51

34. Fardellone P, Sebert JL, Bouraya M, Bonidan O, Leclercq G, Doutrellot C, Bellony R, Dubreuil A (1991) Evaluation of the calcium content of diet by frequential self-questionnaire. Rev Rhum Mal Osteo-artic 58:99-103

35. Boutroy S, Bouxsein ML, Munoz F, Delmas PD (2005) In vivo assessment of trabecular bone microarchitecture by highresolution peripheral quantitative computed tomography. J Clin Endocrinol Metab 90:6508-6515

36. MacNeil JA, Boyd SK (2007) Accuracy of high-resolution peripheral quantitative computed tomography for measurement of bone quality. Med Eng Phys 29:1096-1105

37. Parent AS, Teilmann G, Juul A, Skakkebaek NE, Toppari J, Bourguignon JP (2003) The timing of normal puberty and the age limits of sexual precocity: variations around the world, secular trends, and changes after migration. Endocr Rev 24:668-693

38. Frisch RE, Revelle R (1970) Height and weight at menarche and a hypothesis of critical body weights and adolescent events. Science 169:397-399

39. Euling SY, Herman-Giddens ME, Lee PA, Selevan SG, Juul A, Sorensen TI, Dunkel L, Himes JH, Teilmann G, Swan SH (2008) Examination of US puberty-timing data from 1940 to 1994 for secular trends: panel findings. Pediatrics 121(Suppl 3):S172-S191

40. Wattigney WA, Srinivasan SR, Chen W, Greenlund KJ, Berenson GS (1999) Secular trend of earlier onset of menarche with increasing obesity in black and white girls: the Bogalusa Heart Study. Ethn Dis 9:181-189

41. Lee PA, Guo SS, Kulin HE (2001) Age of puberty: data from the United States of America. APMIS 109:81-88

42. Euling SY, Selevan SG, Pescovitz OH, Skakkebaek NE (2008) Role of environmental factors in the timing of puberty. Pediatrics 121(Suppl 3):S167-S171

43. Kaplowitz PB (2008) Link between body fat and the timing of puberty. Pediatrics 121(Suppl 3):S208-S217

44. Bourguignon JP (2004) Control of the onset of puberty. In: Pescovitz OH, Eugster E (eds) Pediatric endocrinology: mechanisms, manifestations and management. Lippincott Wiliams \& Wilkins, Philadelphia, pp 285-298 
45. Aksglaede L, Juul A, Olsen LW, Sorensen TI (2009) Age at puberty and the emerging obesity epidemic. PLoS ONE 4:e8450

46. Aksglaede L, Sorensen K, Petersen JH, Skakkebaek NE, Juul A (2009) Recent decline in age at breast development: the Copenhagen puberty study. Pediatrics 123:e932-e939

47. Wells JC, Cole TJ (2002) Adjustment of fat-free mass and fat mass for height in children aged $8 \mathrm{y}$. Int $\mathrm{J}$ Obes Relat Metab Disord 26:947-952

48. Davies PS, Wells JC (1994) Calculation of total body water in infancy. Eur J Clin Nutr 48:490-495

49. Anderson SE, Dallal GE, Must A (2003) Relative weight and race influence average age at menarche: results from two nationally representative surveys of US girls studied 25 years apart. Pediatrics 111:844-850

50. Wang Y (2002) Is obesity associated with early sexual maturation? a comparison of the association in American boys versus girls. Pediatrics 110:903-910

51. Trussell J (1978) Menarche and fatness: reexamination of the critical body composition hypothesis. Science 200:1506-1513

52. Trussell J (1980) Statistical flaws in evidence for the Frisch hypothesis that fatness triggers menarche. Hum Biol 52:711-720

53. Garn SM, LaVelle M, Rosenberg KR, Hawthorne VM (1986) Maturational timing as a factor in female fatness and obesity. Am J Clin Nutr 43:879-883

54. Bronson FH, Manning JM (1991) The energetic regulation of ovulation: a realistic role for body fat. Biol Reprod 44:945-950

55. de Ridder CM, Thijssen JH, Bruning PF, Van den Brande JL, Zonderland ML, Erich WB (1992) Body fat mass, body fat distribution, and pubertal development: a longitudinal study of physical and hormonal sexual maturation of girls. J Clin Endocrinol Metab 75:442-446

56. Beunen GP, Malina RM, Lefevre JA, Claessens AL, Renson R, Vanreusel B (1994) Adiposity and biological maturity in girls 616 years of age. Int J Obes Relat Metab Disord 18:542-546

57. Frisch RE, Revelle R (1971) Height and weight at menarche and a hypothesis of menarche. Arch Dis Child 46:695-701
58. Zacharias L, Wurtman RJ (1969) Age at menarche. genetic and environmental influences. N Engl J Med 280:868-875

59. Fischbein S (1977) Intra-pair similarity in physical growth of monozygotic and of dizygotic twins during puberty. Ann Hum Biol 4:417-430

60. Kaur DP, Singh R (1981) Parent-adult offspring correlations and heritability of body measurements in a rural Indian population. Ann Hum Biol 8:333-339

61. Treloar SA, Martin NG (1990) Age at menarche as a fitness trait: nonadditive genetic variance detected in a large twin sample. Am J Hum Genet 47:137-148

62. Baxter-Jones AD, Helms P, Baines-Preece J, Preece M (1994) Menarche in intensively trained gymnasts, swimmers and tennis players. Ann Hum Biol 21:407-415

63. Kaprio J, Rimpela A, Winter T, Viken RJ, Rimpela M, Rose RJ (1995) Common genetic influences on BMI and age at menarche. Hum Biol 67:739-753

64. Salces I, Rebato EM, Susanne C, San Martin L, Rosique J (2001) Familial resemblance for the age at menarche in Basque population. Ann Hum Biol 28:143-156

65. Ettinger B, Sidney S, Cummings SR, Libanati C, Bikle DD, Tekawa IS, Tolan K, Steiger P (1997) Racial differences in bone density between young adult black and white subjects persist after adjustment for anthropometric, lifestyle, and biochemical differences. J Clin Endocrinol Metab 82:429-434

66. Hui SL, Perkins AJ, Harezlak J, Peacock M, McClintock CL, Johnston CC Jr (2010) Velocities of bone mineral accrual in black and white American children. J Bone Miner Res 25:1527-1535

67. Li JY, Specker BL, Ho ML, Tsang RC (1989) Bone mineral content in black and white children 1 to 6 years of age. early appearance of race and sex differences. Am J Dis Child 143:1346-1349

68. Rupich RC, Specker BL, Lieuw AFM, Ho M (1996) Gender and race differences in bone mass during infancy. Calcif Tissue Int $58: 395-397$ 